Valóságos könyvtár - könyvtári valóság. Könyvtár- és információtudományi tanulmányok 2020. Szerk. Kiszl Péter, Boda Gáborné Köntös Nelli.

Budapest, ELTE BTK Könyvtár- és Információtudományi Intézet. 2021. 255-266.

\title{
A FŐVÁROSI SZABÓ ERVIN KÖNYVTÁR 2018. ÉVI HASZNÁLÓI ELÉGEDETTSÉG- ÉS IGÉNYFELMÉRÉSÉNEK NÉHÁNY TANULSÁGA
}

\section{DIPPOLD PÉTER}

\author{
ELTE BTK KITI Információtudományi Tanszék, egyetemi adjunktus; \\ Fővárosi Szabó Ervin Könyvtár Központi Könyvtár, igazgató
}

\section{TARTALMI ÖSSZEFOGLALÓ}

Az elégedettség- és igényfelmérés 2018. április 18. és május 2. között történt a Fơvárosi Szabó Ervin Könyvtár valamennyi tagkönyvtárában, hagyományos és online kérdőívek kitöltésével. A kérdőíveket 2505 használó töltötte ki, ez a mennyiség elegendőnek látszik a speciális igények megismerése mellett általános következtetések levonására is.

A tanulmány azt követi végig, hogyan jelennek meg a közkönyvtárak fejlődésének trendjei a felmérésben. A felmérés néhány jellemző eredményét ábrázoló grafikon bemutatása tényekkel támasztja alá a könyvtárosok gyakorlati tapasztalatait. Egy könyvtári üzem felelős menedzsmentje döntéseit nem megérzésekre alapozza. A használói elégedettség- és igényfelmérés többek között azt szolgálta, hogy a döntések valódi mérési eredményekre, adatokra támaszkodjanak.

Az elégedettség- és igényfelmérés 2018. április 18. és május 2. között készült a Fővárosi Szabó Ervin Könyvtár (FSZEK) valamennyi tagkönyvtárában, hagyományos és online kérdőívek kitöltésével. A kérdőíveket 2505 használó töltötte ki, ez a mennyiség elegendőnek látszik következtetések levonására. A felmérés részletes eredményei a könyvtár honlapján elérhetők. ${ }^{1}$ Ezen tanulmány célja nem a kérdőívekre adott válaszok részletes elemzése, hanem a közkönyvtárak fejlesztési trendjeinek összevetése a felmérés eredményeivel.

Melyek ezek a trendek? Szerepel közöttük a könyvtárlátogatások céljának sokszínűsége a közkönyvtárakban, a számítógép-használati szokások változása és a természetes igény az internet ingyenes elérésére. Az ilyen típusú felmérésekből értesülhetünk - többek között - a használók és a könyvtárosok közötti személyes kapcsolatok fontosságáról, az épülettel, bútorzattal kapcsolatos elvárásokról és a közösségi térként való használat mértékéről.

A két évvel ezelőtti konferencián a „Long Tail” jelenség kapcsán vázlatos képet próbáltam nyújtani a Fővárosi Szabó Ervin Könyvtár Központi Könyvtára és a hálózati könyvtárak kölcsönzési statisztikáiról. ${ }^{2}$ Jól megfigyelhető különbség fedezhető fel a központ és a hálózat kölcsönzési szokásaiban, köszönhetően elsősorban a funkcióbeli 


\section{DIPPOLD PÉTER}

eltéréseknek. Tovább folytatva vizsgálódásomat, a szolgáltatások iránti igények különbségei is kimutathatók az intézményen belül a kérdőívre adott válaszok alapján.

A felmérés ugyanakkor nemcsak a különbségekre, hanem az intézményi szinten megjelenó általánosabb trendekre is adatokat nyújt, ami a további fejlesztések alapját jelentheti, s arra is alkalmat ad, hogy - különösen a szolgáltatások területén - meghatározza a könyvtár szolgáltatásfejlesztési stratégiájának pilléreit.

\section{A könyvtár használói köre és reprezentációja a felmérésben}

Az utóbbi évek hivatalos könyvtárstatisztikái a Fővárosi Szabó Ervin Könyvtárra vonatkozóan azt mutatják, hogy a 14 éven aluliak aránya körülbelül 15\%-ot, a 14 és 65 év közöttiek körülbelül 75\%-ot, míg a 65 év felettiek hozzávetőleg 10\%-ot tesz ki az összes regisztrált használóból. ${ }^{3}$ Ezzel szemben a kérdőívet a különböző korcsoportok nem pontosan ebben az arányban töltötték ki: nem szerepeltek a felmérésben a 14 év alattiak, a 14-65 év közötti kategóriát pedig a kérdőívben három korosztályra bontottuk (1. ábra).

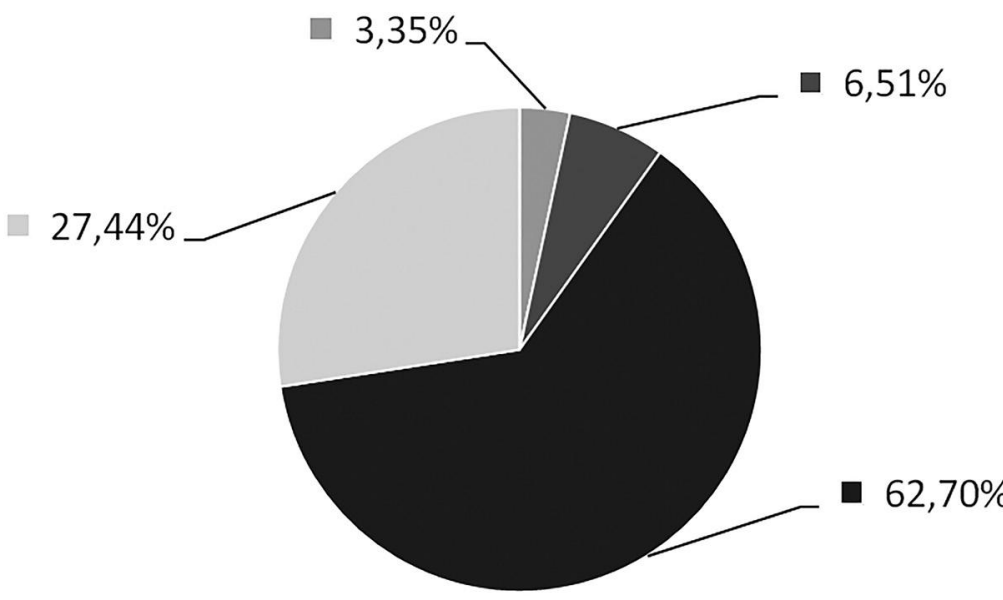

\section{5-18 éves $\square$ 19-25 éves $\square$ 26-65 éves $\quad 65$ év felett}

\section{1. ábra: A válaszolók kor szerinti megoszlása a 2018-as felmérés alapján}

Az 1. táblázat azt mutatja, hogy a mindkét forrásban meglévő 14-65 év közötti korosztály képviselete a kérdőív kitöltői között körülbelül a tényleges használókat reprezentáló, míg a nyugdíjas korosztály aránya a kitöltôk között jóval magasabb, mint tényleges létszámuk a könyvtár használói között. Az adatok eltérése azt mutatja, hogy a kérdőív kitöltésére a 65 év feletti korosztály hajlamosabb volt, mint az idővel ke- 
vésbé rendelkező fiatalabbak. A 14 év alatti fiatalok értelemszerúen nem töltöttek ki kérdőíveket, az őket érintő kérdésekre legfeljebb szüleik reflektáltak, ez azonban a feldolgozás során nem követhető.

\section{1. táblázat}

A bivatalos statisztikea és a kérdôivet kitöltöke életkor szerinti arányának összehasonlitása

\begin{tabular}{|l|c|c|}
\hline \multicolumn{1}{|c|}{ Korcsoportok } & Hivatalos statisztika 2017 (\%) & Kérdőívet kitöltők 2018 (\%) \\
\hline 14 éven aluliak & 15 & - \\
\hline 14-65 év közöttiek & $\mathbf{7 5}$ & $\mathbf{7 2 , 5 8}$ \\
\hline 15-18 év közöttiek & - & 3,37 \\
\hline 19-25 év közöttiek & - & 6,51 \\
\hline 26-65 év közöttiek & - & 62,70 \\
\hline 65 év felettiek & $\mathbf{1 0}$ & $\mathbf{2 7 , 4 4}$ \\
\hline
\end{tabular}

A kérdőívben lehetőségünk nyílt olyan kérdések feltételére, amelyekre a hivatalos statisztika szintén nem ad választ, így jelentősen pontosíthatjuk tudásunkat a használók iskolai végzettségéről, foglalkoztatottságáról, élethelyzetük és társadalmi helyzetük szerinti megoszlásáról is. Ezek az információk azért fontosak számunkra, mert egyrészt választ adnak arra, mennyire tekinthetjük a véleményeket reprezentatívnak, másrészt lehetővé teszik a célközönségen belüli differenciálást szolgáltatásaink fejlesztésekor.

\section{A könyvtárhas₹nálat célja a teljes intézményben, illetve külön a Központi Könyvtárban}

A teljes intézmény vonatkozásában a 2018-as felmérés azt mutatta ki, hogy a használók több mint fele szórakozásra és személyes érdeklődésének kielégítésére használja a könyvtárat. Szembetűnő még a programok látogatásának népszerűsége - ehhez érdemes tudni, hogy például 2019-ben a hálózati könyvtárakban és a Központi Könyvtárban (KK) több mint 4000 rendezvényen mintegy 145000 látogató vett részt, tehát a valóságban is nagy tömegekrôl van szó (2. ábra). 


\section{DIPPOLD PÉTER}

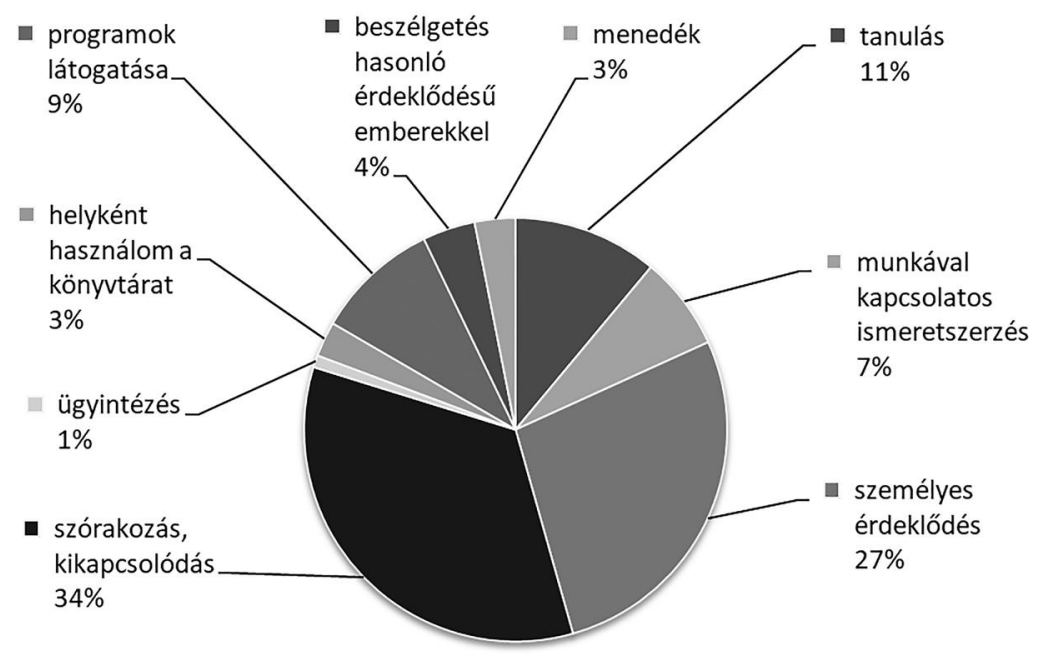

2. ábra: A könyvtárbasználat célja a 2018-as felmérés szerint a teljes intézmény vonatkozásában

2019 novemberében egy egyetemi könyvtári gyakorlat keretében a 2018-as kérdőívből válogatott kérdések alapján kontrollvizsgálatra került sor a Központi Könyvtárban. ${ }^{4}$ A könyvtárba látogató ötven személyt kérdeztünk meg újra személyesen, fóképpen a szolgáltatásokkal kapcsolatos véleményüket firtatva (3. ábra).

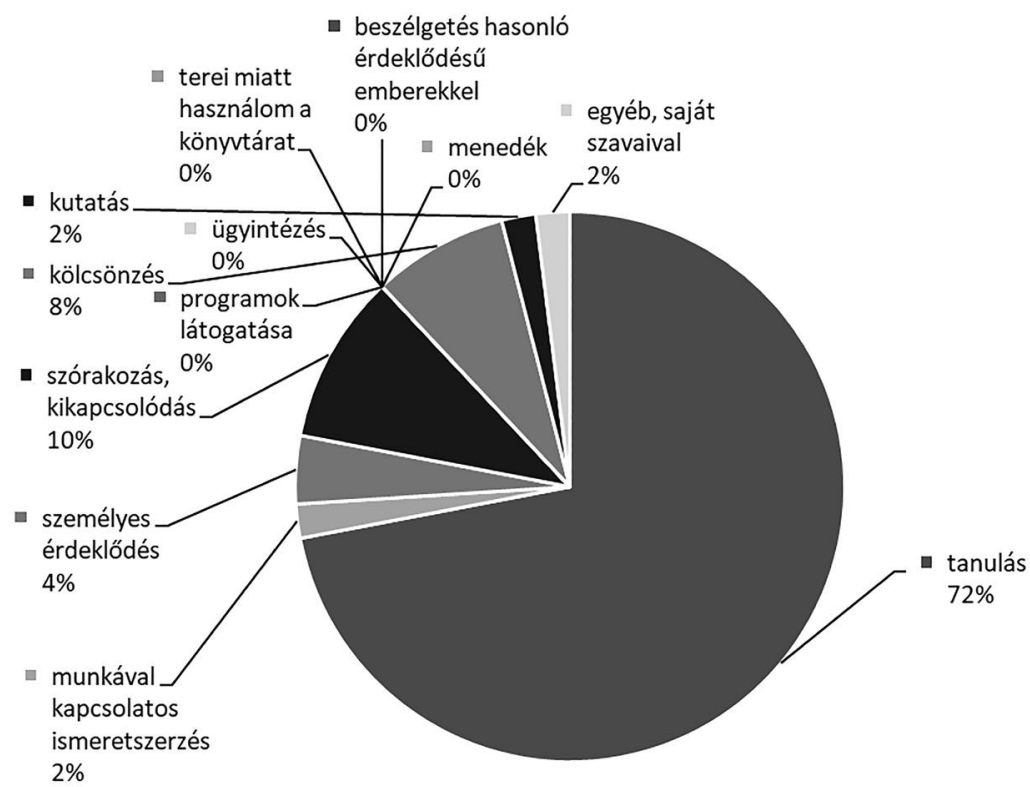

3. ábra: A könyvtárbasználat célja a Központi Könyvtárban 2019-ben elvégzett kontrollvizsgálat alapján 
Már az első kérdéseknél kiderült a teljes intézményre (benne a KK) és a Központi Könyvtárra külön vonatkozó eredmények jelentős különbözősége. Elég, ha a látogatás céljára kérdezünk, és máris látszik az egyetemi könyvtári funkció jelentős hatása a központban, szemben a hálózati könyvtárakra jellemző szórakozási-kikapcsolódási iránynyal. Míg a teljes intézményre vonatkozóan a használók 34\%-a szórakozási és kikapcsolódási céllal és 27\%-a személyes érdeklődése kielégítésre használja a könyvtárat, addig Központi Könyvtárban a tanulás dominált 72\%-kal és csak 4\% látogatja a könyvtárat személyes érdeklődésének kielégítéséért.

\section{Az. ELTE Könyvtár-és Információtudományi Intézete (KITI) hallgatóinak felmérése a FSZEK tagkönyvtáraiban}

2017-ben az ELTE KITI mesterképzésben (MA) résztvevő hallgatói - Kiszl Péter kezdeményezésére és kurzusán - projektmunkaként, az ELTE BTK Könyvtár- és Információtudományi Intézet és a FSZEK stratégiai együttmúködési megállapodásának keretében felmérést végeztek a FSZEK hálózati könyvtáraiban. ${ }^{5}$ A felmérés 2017 őszén valósult meg. A hallgatók a megfigyeléshez használt kérdőívet és szempontrendszert a könyvtárvezetőkkel egyeztetve maguk állították össze. A felmérés célja az volt, hogy a hallgatók megvizsgálják a FSZEK 3 régiójának 3-3 fiókkönyvtárát (összesen 9 könyvtárt), egyenként értékelve a tagkönyvtárak adottságait és teljesítményét. A személyes tapasztalatok és a kérdőívek elemzése nyomán az egyes könyvtárak munkájának megismerése mellett a hallgatók áttekintést szereztek a hálózat múködéséről is. A felmérésben nem szerepelt a Központi Könyvtár.

A kérdőív a könyvtárak megközelíthetőségének, külső láthatóságának feltérképezése mellett kitért a belső adottságokra: a bútorokra, a világításra, a mellékhelyiségek állapotára és a feliratok egyértelmúségére is. Külön kérdések mérték fel az IT fejlettségét: mennyire használhatók és korszerűek az olvasói terek, illetve a könyvtárosok gépei; van-e lehetőség nyomtatni vagy szkennelni a bibliotékákban. Ehhez a kérdéscsoporthoz csatlakozott a wifi és internetkapcsolat minőségének áttekintése, valamint az egyes tagkönyvtárak aktivitásának vizsgálata a közösségi platformokon. Nem hagyható ki egy áttekintésből az állományok nagyságának és rendezettségének felmérése, és természetesen a szolgáltatások minőségének értékelése sem. Külön kérdéscsoport foglalkozott a könyvtárosok személyiségével, illetve ennek fontosságával az emberi kapcsolatok kialakításában.

A vizsgálat eredménye egy 33 oldalas dokumentum lett, amelyben a hallgatók az egyes könyvtárak értékelése mellett általános, a hálózat múködésére vonatkozó következtetéseket is levontak. A felmérés értékelése az ELTE Könyvtár- és Információtudományi Intézete, az érintett könyvtárak, illetve a FSZEK vezetőinek aktív részvételével, jó hangulatú személyes találkozás keretében történt 2017. november 30-án. A vizsgálat megállapításai beépültek az egyes tagkönyvtárak mindennapi tevékenységébe. 


\section{DIPPOLD PÉTER}

Szolgáltatásokekal kapcsolatos adatok, igények, elégedettség a 2018-as felmérés alapján

A 4. ábrán látható szolgáltatások közül a wifire, illetve a könyvtári számítógépek használatára vonatkozó témákat emelem ki.

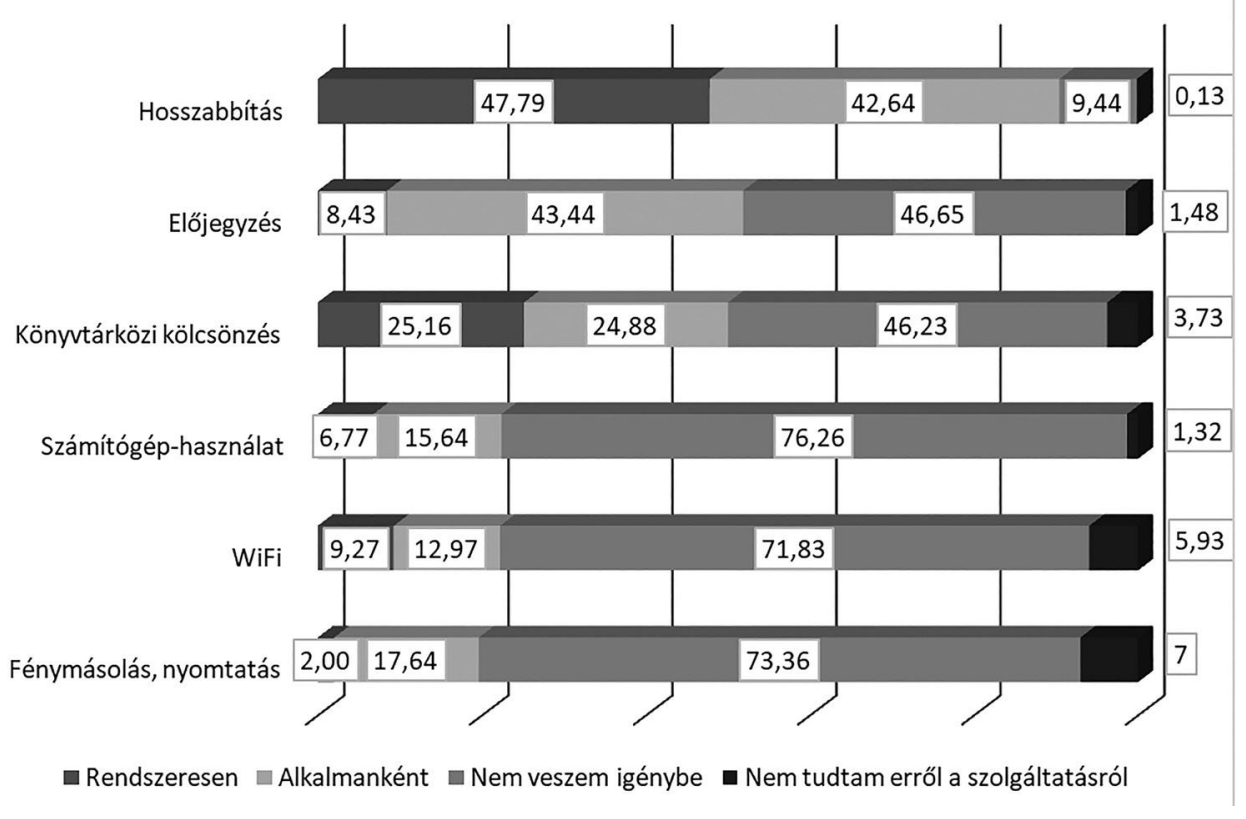

4. ábra: A belyben has:nált szolgáltatások, használati adatai a 2018-as felmérés alapján (\%)

Minden trend arra mutat, hogy az ingyenes wifi használat előbb-utóbb általánossá és megszokottá válik országszerte, és ebből nyilván nem maradhatnak ki a könyvtárak sem. Az egyes kerületek, illetve a fővárosi önkormányzat és különböző cégek (pl. BKK, MÁV, HÉV) és vállalkozások (éttermek, kávézók stb.) egyre több helyen teszik ingyenesen elérhetôvé az internetet.

Könyvtárunkban a helyzet 2018-ban úgy alakult, hogy beiratkozott olvasóink számára ingyenessé tettük a wifi használatát, míg a regisztrációval rendelkezők továbbra is térítés ellenében vehették igénybe a szolgáltatást. Nem titkolt célunk volt, hogy ezzel is ösztönözzük olvasóinkat a beiratkozásra, amellyel könyvtárunk sokkal szélesebb körű szolgáltatásait is használhatják. A Használati Szabályzat 2020. évi módosításának vitáján a könyvtár vezetősége a wifi használatot a regisztrált használók számára is ingyenessé tette, így gyakorlatilag minden könyvtárba belépő használó igénybe veheti.

Ami a számítógép-használatot illeti, az a trend figyelhető meg, hogy általában csökken a könyvtári gépek használata, egyre többen használják saját mobil-eszközeiket az internetezésre. Ennek következtében - mivel csökken az igény - a hálózati könyv- 
tárak sorra csökkentik a gépek számát, és a felszabaduló helyeket olvasóhellyé vagy közösségi tevékenységekre alkalmas hellyé alakítják át.

A 2019. novemberi kontroll-felmérésben a Központi Könyvtár esetében különösen jellemző grafikon (5. ábra) illusztrálja ezt a trendet, a válaszadó olvasók alig több mint negyede használja csak a könyvtári gépeket.

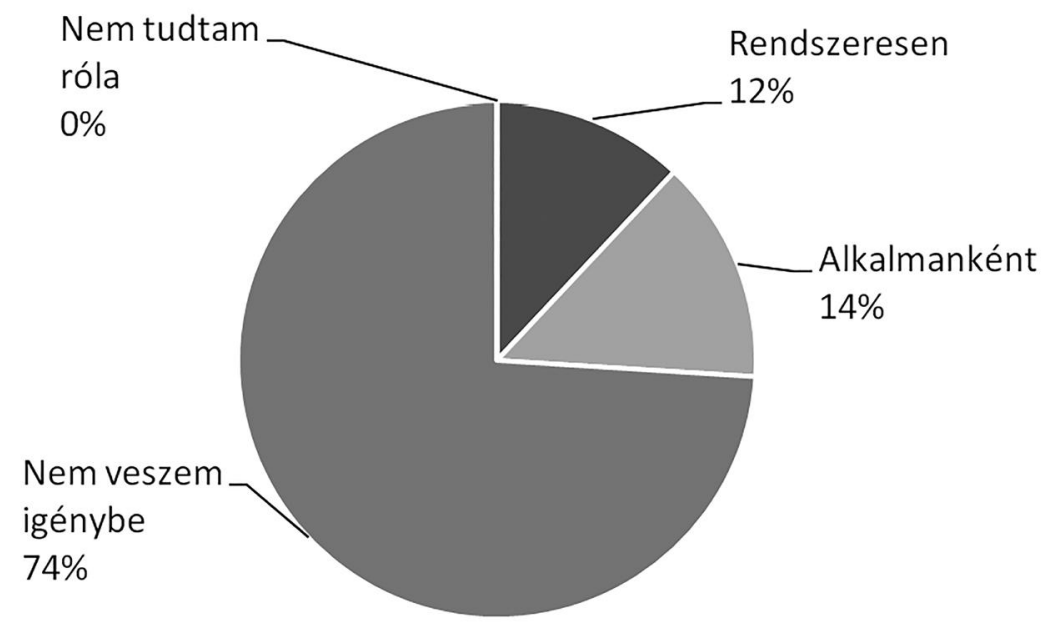

5. ábra: A sqámitógépek használatának megoszlása a Központi Könyvtárban a 2019-es kontrollvizsgálat alapján

\section{Has₹nálat közösségi térként}

A közkönyvtárak jövőjének egyik kulcsa közösségi térként való működésük. Ennek több összetevője van, többek között a könyvtárépület elhelyezkedése a városi térben, az akadálymentes közlekedés lehetősége, az épületen belüli építészeti megoldások, a tisztaság vagy a bútorok kényelme. A használói felmérésben több kérdés is foglalkozott ezzel a funkcióval. Ezek közül egyet emelek ki, amely a könyvtári tér komfortosságára kérdez rá.

A grafikonból (6. ábra) kiolvasható, hogy a használók általánosságban inkább elégedettek a körülményekkel, mint nem. Ugyanakkor három területen figyelhető meg az elégedetlenség nagyobb aránya: a klimatizáltság, a mellékhelyiségek állapota és a ruhatár vonatkozásában. A fővárosi könyvtári hálózat 49 tagkönyvtára természetesen nem egységes ezeken a területeken, van, ahol megfelelőek vagy kiválóak a körülmények, de vannak könyvtárak, ahol akad még tennivaló a javításra. Éppen a felmérés megállapításainak hatására 2019 tavaszán a könyvtár vezetősége teljes körű bejárást végzett, egyenként vizsgálva az egyes tagkönyvtárak helyzetét. A bejárás eredményei alapján cselekvési terv készült, amely a hiányosságok felszámolását tartalmazza rövid-, középés hosszú távú időintervallumban. 


\section{DIPPOLD PÉTER}

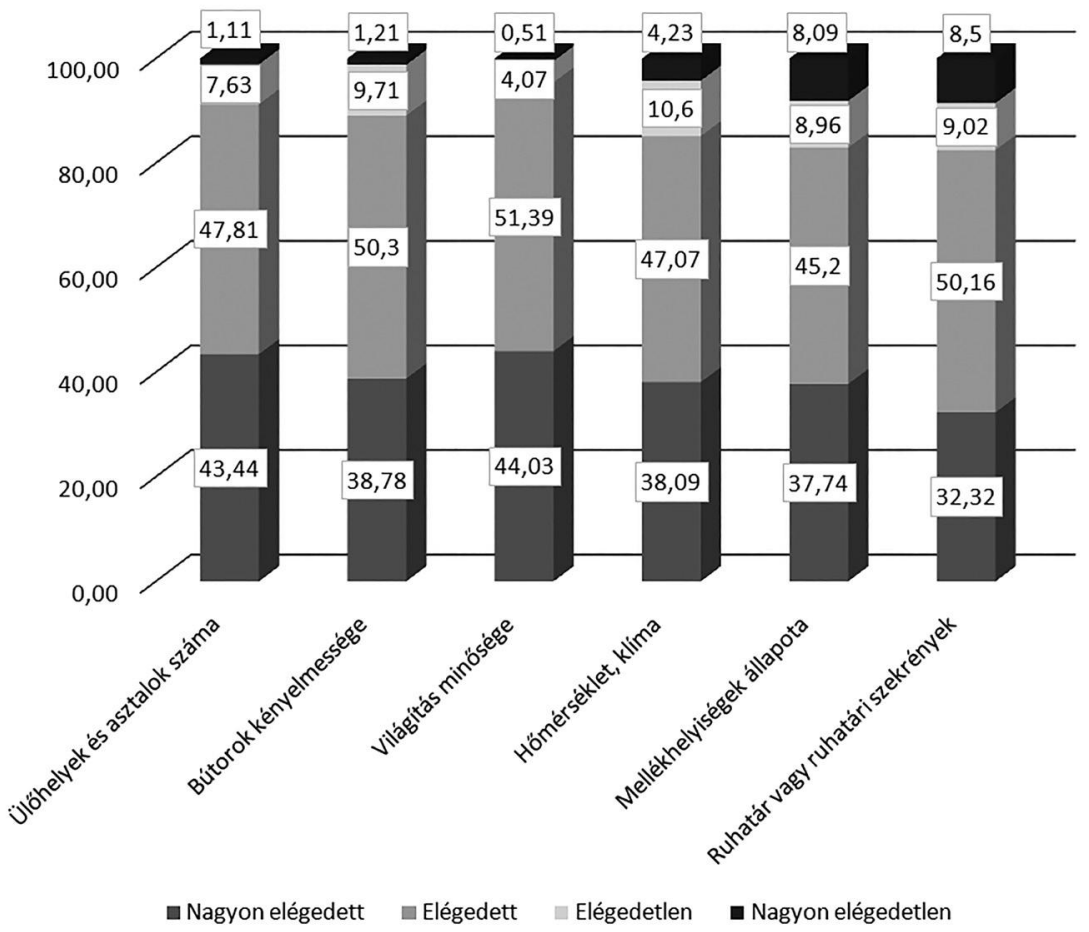

6. ábra: A könyvtári terek komfortosságával való elégedettség a 2018-as felmérés alapján

A Központi Könyvtár vonatkozásában a 2019. novemberi kontrollvizsgálat a 7. ábrán látható.

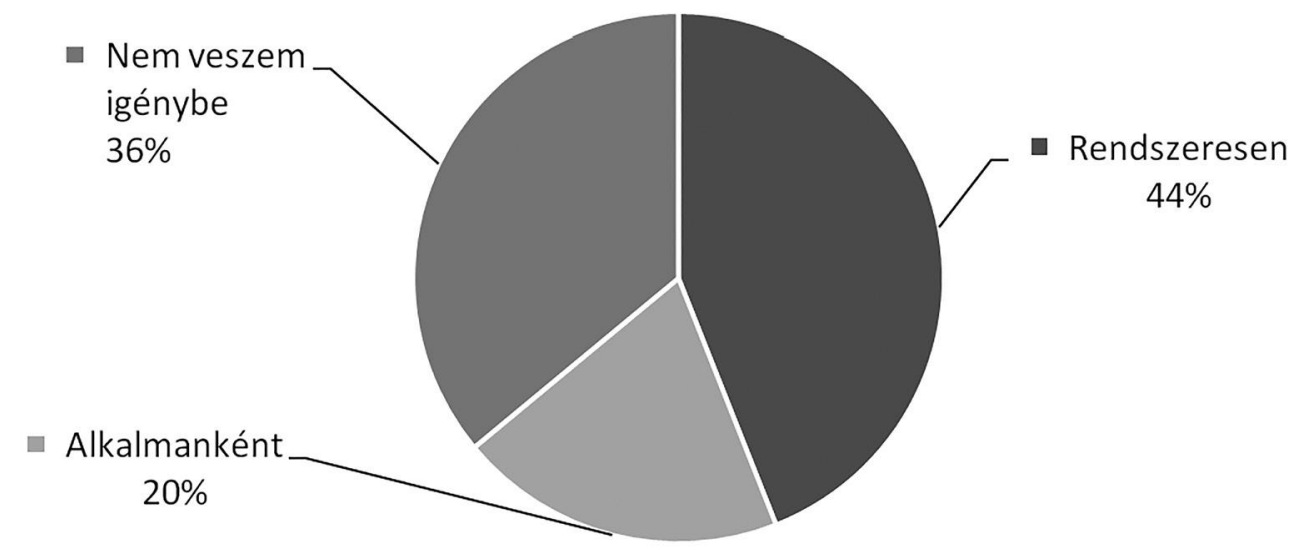

7. ábra: A Központi Könyvtár közösségi térként való hasznnálata a 2019-es kontrollvizsgálat alapján 
A 2018-as vizsgálat eredményei is azt mutatják, hogy a közösségi térként való használat a Központi Könyvtárban a legnagyobb arányú. A hálózati könyvtárakban valamivel kisebb értékek figyelhetôk meg, a rendszeres használat 10\% körül, míg az alkalmankénti használat $23 \%$ körül mozog. ${ }^{6}$

\section{Információkérés közvetlenül a könyvtárostól}

A diagram (8. ábra) elemzése során megállapíthatjuk, hogy a könyvtáros információnyújtó szerepe manapság is megkerülhetetlen. Mindössze 7\% azon olvasók aránya, akik nem veszik igénybe a könyvtáros személyes tájékoztatását. Ezzel párhuzamosan a válaszolók közel 60\%-a használja a könyvtárban használható katalógusokat (számítógépes). A könyvek és folyóiratok helyben olvasásának viszonylagos népszerűsége mellett fontos adat, hogy a válaszolók több mint 40\%-a adatbázis használónak vallotta magát.

A Központi Könyvtárban kevesebben keresik rendszeresen a könyvtárost, leginkább a kisebb könyvtárakban népszerű a szóbeli információkérés. Ennek oka többek között az automatikus kölcsönzés bevezetése, a sokkal nagyobb tömeg, valamint a már említett, tanulóhelyként történő használat népszerűsége.

Információkérés, tájékoztatás a könyvtárosoktól

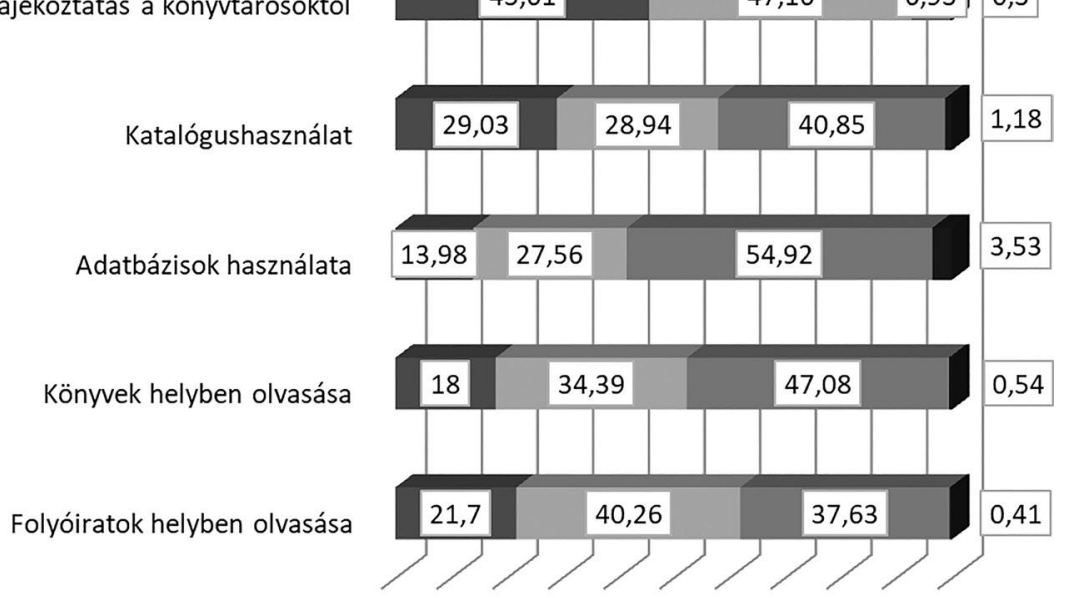

¿ Rendszeresen $\square$ Alkalmanként $\square$ Nem veszem igénybe $\square$ Nem tudtam erről a szolgáltatásról

8. ábra: Helyben has ználható szolgáltatások igénybevételének gyakorisága a 2018-as felmérés szerint 


\section{DIPPOLD PÉTER}

A kérdőívben lehetőséget adtunk a használóknak egyéni véleményük kifejtésére is. Tanulságos volt megfigyelni a pozitív vélemények túlsúlyát, de természetesen olykor kritikákat is megfogalmaztak a könyvtárakkal szemben. A könyvtárosok megítélésével kapcsolatban néhány véleményt idézek:

A pozitívak:

„Nagyon elégedett vagyok a könyvtárosok munkájával, rendsz̨eresen viszem az osztályomat hozzájuk, segitenek idös szülleimnek is könyveket válasz̧tani, ajánlanak nekünk olvasnivalót és rugalmasak, kedvesek. Köszönöm a munkájukat?'

(Krúdy Gyula Könyvtár, Fő tér 5.)

„Nagyon meg vagyok elégedve a könyvtárban dolgozók munkájával, megfelelöen tájékoztatnak mindenröl. Rendszeresen felhivják a figyelmet az üjdonságokra, a lehetöségekre.”

(Deák Ferenc Könyvtár, Rottenbiller u. 10.)

A kevésbé „lelkizősök” (valószínűleg fiatalok):

„Nagyon különbözó" habitusúak a könyvtárosok, igy sztem nem lehet egységesen értékelni, hogy milyenek. Nekem az is fontos, bogy gyors legyen a kiszolgálás, ne kelljen sokáig sorban állni, vagy ne tartson soká az ügyintézés."

(Király utcai könyvtár)

... és a kritikusak:

„tényleg lehetnének türelmesebbek és kedvesebbek a dolgozók."

(Központi Könyvtár)

\section{A szolgáltatások ismertsége a hasænálók körében}

Több szolgáltatásunkkal kapcsolatban tettünk fel kérdéseket, amelyekben az egyes szolgáltatások ismertségére és a velük való elégedettségre kértünk információkat (9.ábra). 


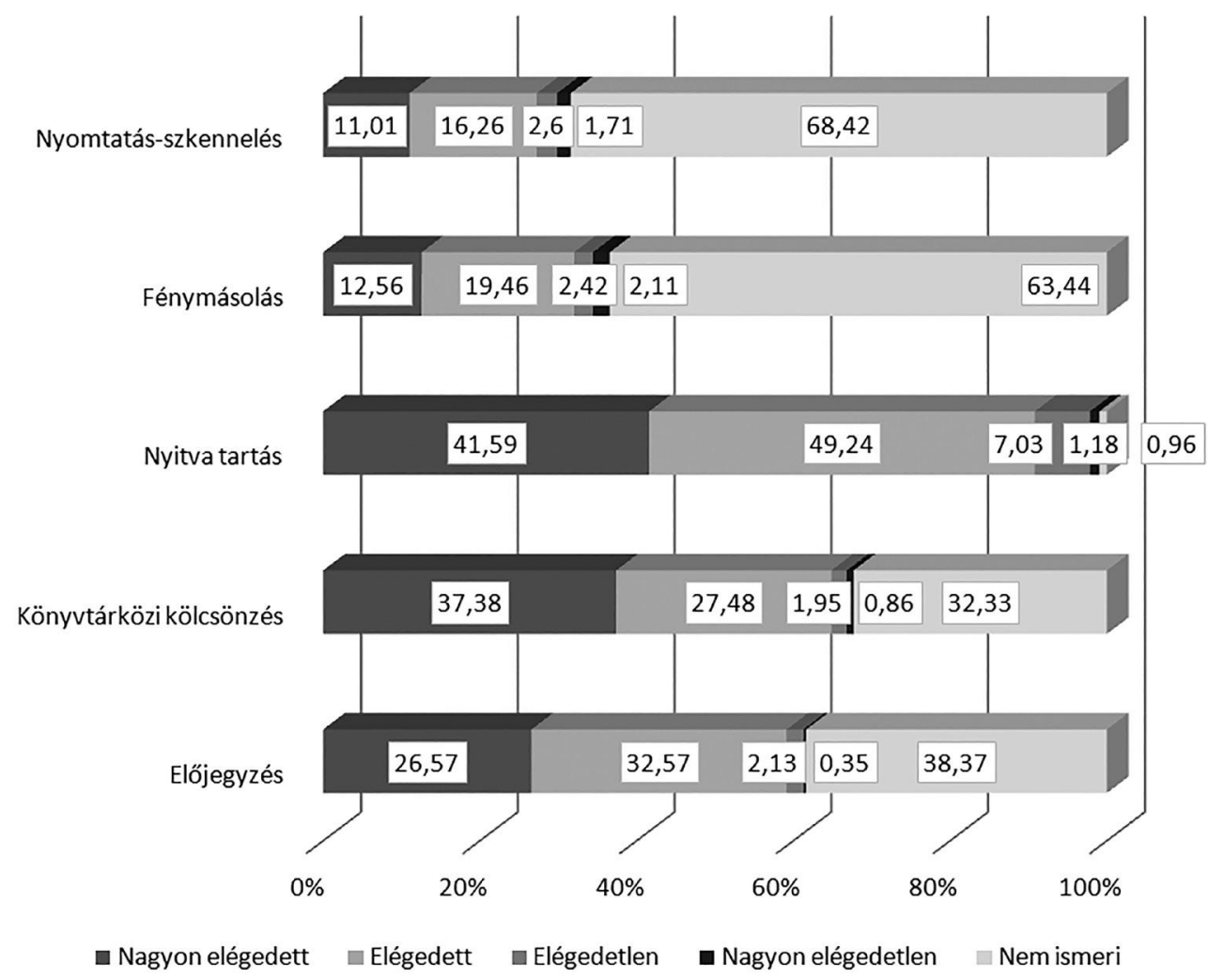

9. ábra: Egyes szolgáltatások ismertsége és népszerüsége az egyes könyvtárakban a 2018-as felmérés szerint

Általánosságban elmondható, hogy a nyitvatartási időt saját könyvtára vonatkozásában szinte mindenki ismeri, és általánosságban elégedettek vele (90,83\%). Ha azonban könyvtártípusonként bontjuk a válaszokat, árnyaltabb képet kapunk, ami egyébként a szöveges megjegyzésekben is megjelenik. A Központi Könyvtár olvasói között kevesebb az elégedett és több az elégedetlen kitöltő. Érdekesnek találhatjuk, hogy éppen azzal a könyvtárunkkal a legkevésbé elégedettek, amely heti 56 óra nyitvatartással országos szinten is kiemelkedő közkönyvtár. Világossá válik azonban a helyzet, ha figyelembe vesszük, hogy a Központi Könyvtár olvasóinak csaknem a fele egyetemista, s a kérdőívet kitöltők több mint 60\%-a tartozik közéjük - az ő igényeik pedig speciálisak e téren: főleg vizsgaidőszakban hosszabb, sőt a teljes hétvégére kiterjedő nyitvatartást várnának el. ${ }^{7}$ Ez a tény éppen a Központi Könyvtár harmadik, jogszabályokban és költségvetési támogatásban láthatatlan, egyetemi könyvtári funkciójából fakad. 


\section{DIPPOLD PÉTER}

\section{A felmérések. basznosulása a könyvtár munkájában}

Mint bevezetőmben említettem, ezen cikk célja nem a felmérések eredményeinek részletes elemzése, inkább a trendszerú jelenségek ismertetése volt. Bár talán úgy túnik, a korábbiakban kiemelt témák mindenki számára ismertek, egy könyvtári üzem felelős menedzsmentje döntéseit nem megérzésekre alapozza. A használói elégedettség- és igényfelmérés többek között azt szolgálta, hogy a döntések valódi mérési eredményekre, adatokra támaszkodjanak.

\section{Jegyzetek és irodalom}

1. FSZEK Primer kutatások munkacsoport (kész.): Használói elégedettség- és igényfelmérés a Fővárosi Szabó Ervin Könyvtárban. Budapest, FSZEK, 2018. Jóváhagyta: FSZEK MIT. 133 p. Forrás: http://www.fszek.hu/rolunk/minosegugy/?article_hid=39240 [2020. február 21.]

2. DIPPOLD Péter: A Long Tail és a könyvtárak. Hogyan kapcsolódhatunk a „hosszú farok” jelenséghez? In: Kiszl Péter - Csík Tibor (szerk.): Valóságos könyvtár - könyvtári valóság: Könyvtár- és információtudományi tanulmányok 2018. Budapest, ELTE BTK Könyvtárés Információtudományi Intézet, 2018. 167-179. p. Forrás: https://doi.org/10.21862/ vkkv2018.167 [2020. február 21.]

3. Fôvárosi Szabó Ervin Könyvtár: 2017. évről szóló statisztikai adatszolgáltatás. Forrás: http:// www.fszek.hu/rolunk/szervezet/statisztika/?article_hid=39027 [2020. február 21.]

4. KERÉKGYÁRTÓ Ágnes (a kérdôivet és az értékelést összeáll.); JUHÁSZNÉ BERECZ Veronika: Használói elégedettségi felmérés a Központi Könyvtárban. Budapest, FSZEK, 2019. (Kézirat)

5. ELTE BTK Informatikus könyvtáros mesterszakos hallgatói (kész.): Fővárosi Szabó Ervin Könyvtár tagkönyvtári felmérése. Budapest, FSZEK, 2017. 33 p. (Kézirat)

6. FSZEK Primer kutatások munkacsoport (kész.): i. m.

7. Uo.

Dippold Péter - a Fővárosi Szabó Ervin Könyvtár Központi Könyvtárának igazgatója, emellett 2016-tól az ELTE BTK Könyvtár- és Információtudományi Intézetének adjunktusa. 2000 és 2005 között a Könyvtári Intézet igazgatója, majd az Országos Széchényi Könyvtár főigazgatóhelyettese. Kutatási területe: a közkönyvtárak fejlesztésének lehetséges irányai az internet korában a trendek tükrében. ORCID: 0000-0001-9000-3392 